\title{
DE NORDISKE KRIMINALISTFORENINGER ÅR 2001
}

I det følgende er en redegørelse for aktiviteter m.v. i det forløbne år i de Nordiske Kriminalistforeninger.

\section{Dansk Kriminalistforening}

Foreningens formand er direktør William Rentzmann. Bestyrelsen bestod i 2001 endvidere af professor Flemming Balvig, professor Ulla Bondeson, landsdommer Hans Henrik Brydensholt, rigsadvokat Henning Fode, dommer Peter Garde, professor Vagn Greve, politimester Lars Rand Jensen, overlæge Peter Kramp, forskningschef Britta Kyvsgaard, lektor Beth Grothe Nielsen, departementschef Michael Lunn og landsdommer Ina Steincke.

Foreningen har sidst på året haft den sorg at miste bestyrelsens sekretær og kasserer, advokat Henrik Viltoft, hvilket er et stort tab for alle, der kendte og arbejdede sammen med ham, og for foreningen. Henrik Viltoft blev medlem af bestyrelsen i 1982 og overtog i 1993 hvervet som sekretær og kasserer. Henrik Viltoft har i hele perioden været et meget aktivt og iderigt medlem af bestyrelsen, og det har været et privilegium at arbejde sammen med ham.

Foreningens æresmedlemmer er højesteretssagfører Jon Palle Buhl og professor, dr. jur. Knud Waaben.

Dansk Kriminalistforening afholdt årsmøde den 31. januar 2001. Samme dag forud for årsmødet holdt foreningen en temadag på Christiansborg om »Etniske minoriteter og retssystemet«. Første oplægsholdere var forskningslektor, ph.d. Lars Holmberg og politimester Jørn Bro, der talte om politiets praksis over for personer med anden etnisk baggrund. Forskningschef Britta Kyvsgaard holdt herefter et indlæg om sammenhæng mellem anholdelse, sigtelse og domfældelse. Efterfølgende belyste advokat Henrik Viltoft og professor, dr. jur. Jens Vedsted Hansen temaet med et indlæg om domstolenes praksis over for personer med anden etnisk baggrund. Sidste indlæg kom fra dr. phil. Jørgen Bæk Simonsen, der talte om andre konfliktløsningsmuligheder inden for eller ved siden af retssystemet.

Dansk Kriminologisk Selskab, der er et datterselskab til Dansk kriminalistforening, arrangerede i foråret 2001 to møder. Den 21. februar talte rigsadvokat Henning Fode om den nye ungdomssanktion, og den 23. april indledte forskningschef, dr. jur. Britta Kyvsgaard og landsdommer Poul Lodberg om strafniveauet i voldtægts- og voldssager.

I efteråret var der ligeledes to møder i selskabet. Professor, dr. jur. Flemming Balvig talte den 10. oktober om kontrolpolitik, velfærdspolitik og tryghed, og læge, ph.d. Ole Brink holdt den 13. november et oplæg om politiets og sundhedsvæsenets samarbejde om voldsstatistikken på baggrund af 20 års erfaringer fra Århus.

Dansk Selskab for International Strafferet og EU-ret, der også er et datterselskab til Dansk Kriminalistforening, afholdt et møde den 6. februar 2001 om Nicetraktaten - et led i udvidelsesprocessen. Mødet blev indledt af kommitteret Sten Frimodt Nielsen, lektor Jens Hartig Danielsen og professor, dr. jur. Henning Koch. 
Derudover er der afholdt et endags-seminar for dommere og anklagere den 22 . marts 2001. Seminaret omhandlede Schengenaftalen, og der var indlæg fra professor Fijnaut, Rotterdam, kontorchef Jakob Scharf, Justitsministeriet og vicepolitichef Olof Egerstedt, Sverige.

Dansk Kriminalistforeningen har desuden to provinsafdelinger, én på Fyn og én i Århus. I begge afdelinger har der været afholdt møder i 2001.

Ved årets udgang havde foreningen 645 medlemmer.

\section{Kriminalistföreningen i Finland - Suomen Kriminalistiyhdistys}

Föreningens styrelse har under året 2001 haft följande sammansättning: Professor Raimo Lahti har fungerat som föreningens ordförande, utvecklingschef Maija Kukkonen har fungerat som föreningens viceordförande, assistent Markus Löfman har fungerat som föreningens sekreterare och direktör Marjatta Kaijalainen som föreningens kassaförvaltare. Styrelsens övriga medlemmar har under året varit följande: direktör Kimmo Hakonen, statsåklagare Päivi Hirvelä, professor Pekka Koskinen, överläkare Kerstin Kronqvist, hovrättsråd Matti Lahti, överlärare Matti Laine, justitieråd Liisa Mansikkamäki, direktör Aimo Myllylä, ledande häradsåklagare Antti Pihlajamäki, kanslichef Ilkka Rautio, överdirektör Markku Salminen, advokat Salme Sandström, konsultativ tjänsteman Tapani Sarvanti och generalsekreterare Hannu Takala.

Professor Inkeri Anttila och socialråd Kaarlo Helasvuo är hedersmedlemmar i föreningen.

Föreningens årsmöte hölls den 7 maj 2001 i Vetenskapernas hus. Huvudtemat vid årsmötet var »Samhällspåföljder i den finländska kriminalpolitiken«. Föreningens viceordförande, utvecklingschef Maija Kukkonen kom med sitt inlägg $i$ ärendet.

Förutom årsmötet ordnade föreningen på våren den 22 mars 2001 vid Helsingfors universitet en diskussionskväll över ämnet »Tillräknelighet, sinnestillstånd och kriminalpatient«. Diskussionen inleddes av hovrättsråd Marianne Wagner-Prenner, överläkare Eira Hellbom, docent i kriminalpolitik Jussi Pajuoja samt docent i kulturantropologi Anna Maria Viljanen. Diskussionskvällen arrangerades tillsammans med Suomalainen Lakimiesyhdistys.

Föreningen ordnade på hösten den 24 september 2001 vid Helsingfors universitet en diskussion över ämnet »Fängelsestraffets framtid - Fängelsestraffkommitténs betänkande 2001:6«. Diskussionen inleddes av lagstiftningsråd Ulla Mohell och regeringsråd Jussi Pajuoja. Professor Martti Majanen kom med sitt förberedda inlägg $\mathrm{i}$ ärendet.

Föreningen ordnade därtill den 21 november 2001 i Vetenskapernas hus tillsammans med Föreningen för europeisk straffrätt en diskussionskväll över ämnet »Bekämpningen av terrorismen - dess reglering, EU och Finland «. Lagstiftningsråd Jukka Lindstedt och överinspektör Harri Sarvanto kom med sina inlägg $i$ ärendet.

Vid årets slut hade föreningen 247 medlemmar. 


\section{Kriminalistforeningen i Island}

Formanden for den Islandske Kriminalistforening er Thorsteinn A. Jónsson, generaldirektør i Fængselsstyrelsen. Sekretær er Svanhildur Sverrisdóttir, økonomichef.

Foreningen har ikke været afholdt møder i 2001.

Ved årets udgang var der 24 medlemmer i foreningen.

\section{Norsk Kriminalistforening}

Formanden for den Norske Kriminalistforening er førstelagmann Nils Erik Lie, Borgarting lagmannsrett. Bestyrelsen består i øvrigt af avdelingsdirektør Toril Øie (nestleder), førstestatsadvokat Inger Marie Sunde, professor Ulf Stridbeck, advokat Ellen Holager Andenæs, tingrettsdommer Wenche Fliflet Gjelsten (vara) og seksjonsleder Paul Larsson (vara). Politimester Anstein Gjengedal har fungeret som sekretær for foreningen, men blev ved årets udgang afløst af førsteadvokat Trond Eirik Schea fra ØKOKRIM.

Der er ikke oplyst om møder i 2001.

Ved årets udgang var der 274 medlemmer i foreningen.

\section{Kriminalistföreningen i Sverige}

Vad gäller föreningens styrelse har rättschefen Fredrik Wersäll 2001 ersatt justitierådet Dag Victor som ordförande och lagmannen Lena Berke har ersatt generaldirektören Anita Werner som styrelseledamot. Styrelsens övriga medlemmar har under året varit: hovrättslagmannen Martin Borgeke, kanslirådet Lotta Gustavson, rikspolischefen Sten Heckscher, överläkaren Stefan Skagerberg, riksåklagaren Klas Bergenstrand, advokaten Thomas Rothpfeffer, häkteschefen Lars- $\AA$ ke Pettersson, professorn Hanns von Hofer, justitierådet Dag Victor och generaldirektören Ann-Marie Begler. Lotta Gustavson har också fungerat som sekreterare och kassaförvaltare.

Ämnet vid årsmötet var »EU och kriminalpolitiken« med inledningsanförande av ambassadör Dan Eliasson, professor Per-Ole Träskman och riksdagsledamoten Alice Åström.

Vid föreningens höstmöte var ämnet »Ny kriminalpolitik i terrorns spår? « med inledningsanförande av redaktören Maria Abrahamsson, rikspolischefen Sten Heckscher, riksdagsmannen Lars Ohly och regeringens internationella chefsförhandlare Peter Strömberg. Debattledare var justitierådet Bo Svensson.

Föreningen har vidare under året anordnat två kriminalpolitiska pubar i samarbete med Kriminalpolitiska sällskapet. Vid vårpuben presenterade justitieombudsmannen Nils-Olof Berggren sexualbrottskommitténs betänkande (SOU 2001:14).

Vid höstpuben talade statssekreteraren Dan Eliasson över ämnet »Skydd för utsatta kvinnor - Var går gränsen för familjelivets helgd? «.

Vid årets slut hade föreningen 340 medlemmar. 